\title{
Serving two masters: the medical and political careers of Sir Charles Tupper
}

\author{
— Cite as: CMAJ 2017 June 26;189:E866-8. doi: 10.1503/cmaj.170224
}

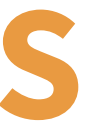
ir William Osler acknowledged the challenge of serving two masters, in his obituary for Sir Charles Tupper but said that Tupper had applied himself fully as a physician and a politician. Tupper was a physician who championed public health, better hospital care and improved medical education. He became a founder and the first president of the Canadian Medical Association (CMA). At the same time, he was a formidable provincial and then federal politician, a Father of Confederation and prime minister of Canada. Osler recognized the unique contribution of this combination in his comment, "His life is an illustration of the brilliant success of the doctor in politics." 1

Sir Charles Tupper was born in Amherst, Nova Scotia, on July 2, 1821. Early in life, he saw himself as a physician, not a politician. His education was initially at home and directed by his father, a Baptist minister who wrote scholarly religious tracts. His parents were both descendants of New England Planters who arrived in the Maritimes after the expulsion of the Acadians. In 1835, at age 15, Tupper apprenticed in Amherst with Dr. Benjamin Page and then with Dr. Ebenezer Harding in Windsor, Nova Scotia, before applying to study medicine at Edinburgh University. The university accepted his years as an apprentice, and he was able to complete his medical training in three years. His 1843 thesis on obstetrics was put forward for a university medal by his mentor, James Young Simpson (who introduced chloroform as an anesthetic). ${ }^{2}$ He had some extraordinary teachers at Edinburgh who believed that medicine was a social good, and this had a profound influence on the young Dr. Tupper.

He began practice in Amherst, where he also opened a pharmacy with his brother that is still in operation. Tupper expected that this would be his life. He served a large rural area with calls as far as 40 miles away. Farmers knew when Tupper was out

on a call; they would find a different horse in their barn, because Tupper exchanged horses on his long routes.

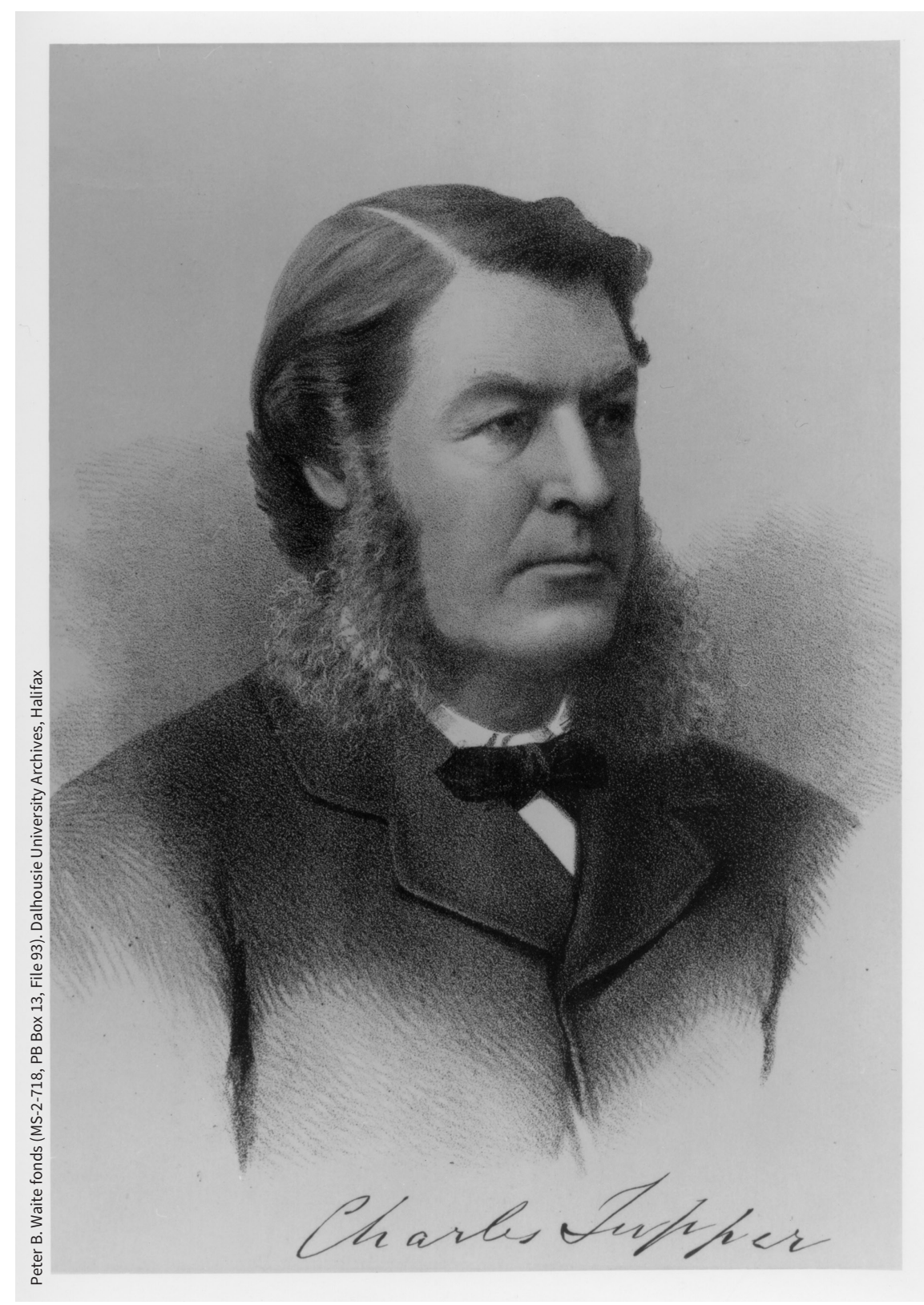

Photograph of Sir Charles Tupper circa 1880. 
His career changed in March 1852 when he agreed to introduce a local Conservative politician who was debating the prominent editor and Liberal politician Joseph Howe. The introduction gave Tupper the opportunity to speak his mind. The force of his reasoned arguments impressed his neighbours and the politicians. It would also be the beginning of a life-long feud between the two men; within a few years Tupper would defeat Howe and become premier of Nova Scotia in 1864 . Both men had strong feelings for Nova Scotia but differing visions. Howe looked inward to Nova Scotia's virtues. Tupper looked outward and saw Nova Scotia as part of a larger British presence in North America and the world.

As premier, Tupper pursued an active political agenda but continued his busy medical practice and also became the medical officer for Halifax. While working for Maritime Union and later Confederation, he passed health-related legislation to bury the open sewers running down the streets of Halifax, dealt with a cholera epidemic, set quarantine laws and established an office of vital statistics.

One of Tupper's first priorities as premier was to establish free, publicly funded education for all children in Nova Scotia, regardless of income, religion or location. He was aware that his own party, the opposition and taxpayers were against the idea. Tupper refused to back down: in 1864, Nova Scotia established the first free nonsectarian education system in British North America. Although not voiced as such at the time, this was a major step forward in improving the determinants of health for this population. The public and the politicians were also getting a taste of the unbending forceful vision of the "fighting doctor" from Amherst.

Not content with reforming primary education, Tupper also looked to establish the struggling Dalhousie University as a nonsectarian institution, which greatly upset his father and the Baptist supporters of his party. He led in getting the university back on its feet and spent years arguing to establish a Dalhousie medical school. The medical society said it was not possible without a general hospital or anatomy act. Tupper pushed for both, as well as a new poor house. Dalhousie Medical School opened in 1868.
Since 1860, Tupper had been working toward a larger end. He envisioned a confederation of the Canadian colonies but wanted to begin with Maritime Union. In 1864, he called the Charlottetown Conference of the Maritime Provinces and invited representatives from Upper and Lower Canada, who came with a desire for that wider confederation. At home in Nova Scotia, he had to contend with a strong anticonfederation movement that was led by Howe, bankers and wealthy merchants. The colonies were prosperous and saw no reason to change the status quo, but Tupper saw confederation as a way for Nova Scotia to become part of a larger presence.

In the 1867 elections in Nova Scotia, 36 of the 38 seats were won by anticonfederationists; federally, 18 of 19 Nova Scotia representatives were anticonfederation. Against these remarkable odds, Tupper brought Nova Scotians into Confederation and kept them there.

The odds were more in his favour when, only a few months later that same year, Tupper was instrumental in bringing together the physicians of the new confederation. Despite his busy schedule, he travelled to Quebec for a meeting at Laval University on Oct. 9, 1867, to discuss the organization of a national medical society. The Quebec hosts felt their society president should be the first president, but Dr. W. Marsten declined, saying that Dr. Charles Tupper would be "a more desirable choice." Tupper was elected unanimously and delivered "an eloquent address," indicating that the new organization would be dedicated to the protection of the health and lives of the people of the nation, and to improving professional qualification and licensure. The members then toured the Beauport Lunatic Asylum. After a fine dinner with many toasts and another speech from the new president, they climbed into 30 carriages and followed Tupper to the St. Louis Hotel for some final libations and sleep. ${ }^{3}$

The first annual CMA meeting was held in Montréal in September 1868. Tupper gave the first presidential address and was interrupted repeatedly by applause and cheers as he spoke about the importance of medical education, regulating the profession and developing a professional code of ethics. At the end of the meeting he was elected for another term; this was repeated the next year, making him the only CMA president to serve three terms.

His presidency was admired, and although the medical politics of the day were often very heated, Tupper was always cool. ${ }^{4}$ He came prepared for whatever issue was raised. His long political experience showed in his leadership of the CMA and gave his decisions "weight and character." The association members "invariably submitted" to his will, showing their complete confidence in him. ${ }^{5}$

Tupper continued to practise medicine wherever he was living during his political life: Halifax, Ottawa, Toronto, and at his summer home in St. Andrew's, New Brunswick. He always had his black bag by his chair in the House of Commons.

Tupper's remarkable half-century record in public service has seldom been surpassed. He was premier of Nova Scotia, and after Confederation and election to Parliament, he served as president of the Queen's Privy Council, minister of internal revenue, minister of customs and minister of railways and canals responsible for building the Canadian Pacific Railway. He authored the national policy for the government of Prime Minister John A. Macdonald. He was appointed high commissioner to London and, just when he was retiring in 1895, was brought back from London to help the Conservative party in the election. He was again elected and when Sir Mackenzie Bowell resigned over Manitoba school issues in 1896, Tupper became Prime Minister, although his party was defeated just 44 days later by Wilfred Laurier.

Politicians of the day were puzzled by Tupper's forthright, aggressive and forceful manner. They were used to Victorian oratory, negotiation and subtle political expediency. He was blunt and unbending in debate. He came to committee rooms armed with facts and did not leave until he achieved what he wanted. When it came to unifying the country, he recognized that John A. Macdonald, with his subtle skills as a conciliator, was better at bringing disparate groups together. Tupper was often the driving force, but Macdonald led the process. Macdonald, 
on the other hand, recognized the value of having Tupper by his side, because he could strong-arm any change. When faced with a political impasse, Macdonald always sent for Tupper. Even Tupper's enemies admired his sheer force, his courage and his demand that government keep its promises.

Tupper was successful because he approached politics not as a politician but as a surgeon. There was none of the lawyer's subtle dancing for him. When something needed to be done, he was determined to do it and would use whatever sharp lancet or blunt instrument was required. It is not surprising that he was admired but not liked.

Tupper came to Macdonald's rescue when The British North America Act was proclaimed on July 1, 1867, and Lord Monck asked Macdonald to form the government. However, it looked like Macdonald would fail and the Hon. George Brown would be tapped instead, because Ontario and Quebec objected to the distribution of Cabinet positions that did not reflect their larger populations. Tupper came to the meeting the next day with a solution. He would give up his position in Cabinet, and he had convinced Thomas D'Arcy McGee from Quebec to do the same, so that additional places would be available to appease Ontario and Que- bec. Seldom do we see such selfless acts in politics. ${ }^{6}$

However, Tupper and Macdonald soon had a falling out over the Canadian Pacific Railway. Tupper believed the railway would tie the country together, and this was his promise to Nova Scotians when he brought them into Confederation. Macdonald was worried about cost overruns. The two friends quarrelled and never reconciled.

Tupper continued as the party's leader until 1901, when he again retired to London at age 82 to be near his daughter Emma and her family. There, he made speeches advocating an alliance of British Commonwealth nations, something that would only come into existence much later. He was the last surviving Father of Confederation when he died in 1915 at the age of 94 . His body was returned to Nova Scotia, where he is buried in Fairview Cemetery alongside his wife and two daughters. A Canadian flag flies over his grave.

Sir William Osler, who was both physician and friend to the more senior Sir Charles Tupper, said Tupper served two masters, medicine and politics, admirably. ${ }^{7}$ Like his contemporary, German pathologist Rudolf Virchow, who was both physician-scientist and politician, Osler believed that "medicine is a social science, and politics nothing else but medicine on a large scale."

\section{T. Jock Murray MD}

Department of Medicine, Division of Neurology, Dalhousie University, Halifax, NS

\section{References}

1. Osler WO. The obituary of Sir Charles Tupper, Bart. BMJ 1915;2862:694-5.

2. Murray TJ, Murray JK. Sir Charles Tupper: fighting doctor to Father of Confederation. Markham (ON): Fitzhenry and Whiteside; 1999.

3. McDermott HE. History of the Canadian Medical Association 1867-1921. Vol. 1. Toronto: Murray Publishing; 1935.

4. Jacques A. How it all began. 1967. CMAJ 1992;147: 1035-8.

5. Canadian Medical Association. Quebec Daily Mercury [Québec City] 1867 Oct. 9, 10, 12.

6. Longley JW. The makers of Canada: Sir Charles Tupper. Toronto: Morang; 1916:87-9.

7. Murray TJ, Murray JK. Serving two masters: the relationship between Sir Charles Tupper and Sir William Osler. In: Barondess JA, Roland CG. The Persisting Osler III. Malabar (FL): Kreiger; 2002:89-100.

8. Ackerknecht EH. Rudolf Virchow: doctor, statesman, anthropologist. Madison (WI): University of Wisconsin Press; 1963:48.

This article has been peer reviewed.

Dr. T. Jock Murray is the author of Sir Charles Tupper: Fighting Doctor to Father of Confederation (Fitzhenry \& Whiteside, 1998).

This article is part of a series that CMAJ is publishing to commemorate the 150th anniversary of the Canadian Medical Association. 